\title{
Sexual differences in foraging behaviour in the Lesser Spotted Woodpecker Dendrocopos minor
}

\author{
Olav Hogstad
}

Hogstad, O. 2010. Sexual differences in foraging behaviour in the Lesser Spotted Woodpecker Dendrocopos minor. - Ornis Norvegica 33: 135-146.

Sexual differences in foraging behaviour in the nearly monomorphic Lesser Spotted Woodpecker (Dendrocopos minor) were studied from 1972 to 2007 in a subalpine woodland in central Norway. Data from different years were pooled and analysed on a seasonal basis: winter (November-February), prebreeding (March-April), breeding (May-June) and autumn (September-October). The predominant foraging substrates were in birch Betula odorata (42\% of 460 foraging observations) and grey alder Alnus incana (44\%). No sexual difference was found in use of dead snags, dying broken trees or live trees, for the four periods separately or combined. Both sexes foraged entirely on dead substrates in winter but with the winter period excluded, females foraged more in live trees and less in snags and broken trees than males. The sexes did not differ in use of tree species, except during the winter when females foraged more in birch (73\%) and less in grey alder $(22 \%)$ than males $(51 \%$ and $49 \%$, respectively). Females foraged in higher live trees of birch (average height $3.8 \mathrm{~m}$ ) and grey alder (4.3 $\mathrm{m}$ ) than males (3.4 m and $3.7 \mathrm{~m}$, respectively) and used substrates with a smaller mean diameter (females: 4.6 $\mathrm{cm}$; males: $5.9 \mathrm{~cm}$ ). The sexes differed in foraging techniques in each of the periods: males used bark-scaling and pecking more than females in all periods, whereas females used more probing than males during the winter and prebreeding periods and more gleaning (picking in the surface of trunks or branches) outside the winter than males. The sexes overlapped in all foraging dimensions except foraging technique where females tended to have a wider foraging niche in winter and prebreeding periods. Low spatial overlap, division the resources by horizontal separation of the habitat, and a divergence in foraging technique between the sexes all suggest that the Lesser Spotted Woodpecker forage in a way that reduces intersexual competition for food in subalpine woodlands with harsh weather conditions.

Key words: Foraging behaviour, foraging technique, intersexual competition, sexual differences, Lesser Spotted Woodpecker, Dendrocopos minor

Olav Hogstad, Norwegian University of Science and Technology, Section of Natural History, NO-7491 Trondheim, Norway.E-mail: Olav.Hogstad@vm.ntnu.no

\section{INTRODUCTION}

Sexual dimorphism in size has been attributed mainly to sexual selection (Andersson 1994) which leads to more pronounced morphological differences in polygamous than in monogamous species (e.g. Møller 1994). Sexual dimorphism may also have evolved through different ecological selection pressures or competition between the sexes for limited resources (e.g. Selander 1966, Slatkin 1984). Woodpecker males are usually larger than females; males in all but two
European species, the Green Woodpecker Picus viridis and the Lesser Spotted Woodpecker Dendrocopos minor, have significantly longer bills or longer wings than females (Cramp 1985). Such sexual dimorphism has been related to sex-specific foraging behaviour in a number of woodpecker species and in some cases, the larger males displace the socially subordinate females from optimal feeding sites (Peters \& Grubb 1983, Hogstad 1991, Matthysen et al. 1991). Such displacements are particularly expected among species in which both sexes inhabit a common 
territory and forage together (Hogstad 1978, Osiejuk 1994).

Because energy requirements increase with decreasing ambient temperature, and there are only a few available hours of daylight to forage in winter in Fennoscandia, Lesser Spotted Woodpeckers as well as other insect-eating birds are probably under considerable energetic constraint during the winter. Thus, avoiding competition with other birds that overlap in food choice may be a priority for individuals. Because male and female Lesser Spotted Woodpeckers are very similar in size, one might expect the sexes to overlap considerably in their use of the habitat and in their foraging behaviour. Hogstad (1978) hypothesized that Lesser Spotted Woodpeckers maintain mutually exclusive winter territories in order to secure sufficient food without wasting energy on conflict over foraging sites.

Competition between members of a pair of Lesser Spotted Woodpeckers could be longlasting because pair bonds generally extend over several years and the birds are philopatric to breeding sites (Wiktander 1998). To reduce any intersexual competition, male and female Lesser Spotted Woodpeckers could partition their foraging niche by 1) maintaining a low spatial overlap between the sexes, i.e. evolving microgeographic allopatry, or by 2) sexual divergence in foraging behaviour. If there is sexual divergence in foraging behaviour, and since the foraging pattern of male woodpeckers is generally more stereotyped than that of females (e.g. Hogstad 1976, 1978, 1991, Peters \& Grubb 1983), it may be suggested that 3 ) the socially dominant males will occupy more optimal microhabitats than females and females will have a broader niche and more variable foraging techniques than the males.

To evaluate these predictions I observed the foraging of Lesser Spotted Woodpeckers in a subalpine woodland over a period of more than 30 years. Although there are some scattered descriptions about the diet of the species (e.g. Pynnönen 1939, Alatalo 1978, Hogstad 1978, Aulén 1988,
Török 1990, Wiktander et al. 1994, Rossmanith et al. 2007), to my knowledge there are no major studies on its foraging behaviour throughout the year or its adaptive significance in relation to minimizing niche overlap between the sexes.

\section{MATERIAL AND METHODS}

\section{The study species}

The Lesser Spotted Woodpecker is the smallest European woodpecker with a total length of $14-16.5 \mathrm{~cm}$ and a mean mass of $24.1 \mathrm{~g}$ (Wiktander 1998). The sexes are not significantly different in lengths of wing, tail, bill or tarsus (Hogstad 1978, Glutz von Blotzheim \& Bauer 1980, Cramp 1985) and have similar plumage except the females lacks the red patch on the head and white forecrown. Small insects comprise the main bulk of diet. In summer, the food consists mostly of caterpillars, aphids, ants, beetles, and other surface-dwelling arthropods, including Diptera and spiders; even small snails are taken. Surface-living insects, such as aphids and caterpillars, are the main nestling food (Török 1990, Wiktander et al. 1994), and about $75 \%$ of the dry weight of all nestling food consists of caterpillars (Török 1990). In winter, wood-boring larvae (e.g. Buprestidae, Cerambycidae, Curculionidae) and those living under bark (e.g. Scolytidae, Ipidae) become important (del Hoyo et al. 2002).

The Lesser Spotted Woodpecker is usually monogamous with a pair-bond that may extend over several years. The annual adult survival varies considerably between years and is higher during warmer winters in Finland (Saari \& Mikusinski 1996) and Norway (Steen et al. 2006), but apparently not in south Sweden (Wiktander 1998), probably due to milder climatic conditions in this part of Fennoscandia. The annual survival of males and females varied in parallel, although females had a lower survival in most years (Olsson 1998, Wiktander 1998). Breeding success varies; in a Swedish study $34 \%$ of attempts failed to produce fledglings (Wiktander et al.2001). The home-range area of 
individually marked Lesser Spotted Woodpeckers in south Sweden decreased from on average 742 ha in winter to a defended territory of 103 ha prior to breeding and only 43 ha during the nesting period (Wiktander 1998).

The Lesser Spotted Woodpecker appears to have declined in many parts of Europe (Mikusinski 1997), largely as a result of loss of deciduous habitats, especially riverine forest and old orchards, which were obviously used extensively. There is marked recent declines of the species in Fennoscandia (Nilsson et al. 1992, Tiainen 1985, del Hoyo et al. 2002, Kålås et al. 2006).

\section{The study area}

The study was carried out in a mixed, subalpine (altitude 550-650 m) woodland of Scots pine Pinus sylvestris and birch Betula odorata in Budal, $90 \mathrm{~km}$ south of Trondheim, in central Norway during the years 1972-2007. Scattered Norway spruce Picea abies, aspen Populus tremula and rowan Sorbus aucuparia trees also occur, and grey alder Alnus incana and sallow Salix caprea are relatively common along rivers and streams. The woodland, which covers approximately $10 \mathrm{~km}^{2}$, is for the most part unmanaged and is characterized by poor vertical stratification of vegetation. The forest extends to about $900 \mathrm{~m}$ above sea level. Most of the study area is covered by snow from November to early May and winters have periods with temperatures between -15 and $-25{ }^{\circ} \mathrm{C}$. The Budal woodland $\left(62^{\circ} 50^{\prime} \mathrm{N}-10^{\circ} 25^{\prime} \mathrm{E}\right)$ is characterized by a semicontinental and slightly oceanic climate. At this latitude daylight period ranges from 4 hrs. 31 min (21 December) to 20 hrs. $37 \mathrm{~min}$. (21 June).

\section{Methods}

Most woodpecker observations are from November to June, with a few from September and October. Two males were caught in mist nets close to their nest trees in May 1996 and 1998 , respectively, and ringed with colour rings but other individuals were not marked. I observed woodpeckers mainly in moist areas, most frequently in patches along rivers or streams with a high degree of decayed wood, mainly of birch and grey alder. To increase sample independence, each individual was recorded only once per day, most often with only one observation per week. As only the first observation of the bird was recorded, the sum of these observations is expected to give a fair estimate of the foraging behaviour (cf. Wiens et al. 1970).

The following data were recorded: 1) sex; 2) whether the bird was foraging alone or in a pair; 3 ) tree species it foraged on; 4) decay status of the substrate: snag (dead stem, 0.5-5m high), broken tree (dying tree with broken top, 1-5 m high) or living tree; 5) condition of foraging substrate (alive or dead); 6) tree height; 7) foraging height; 8) tree-trunk diameter where foraging; 9) foraging technique ("scaling", i.e. systematic removal of bark on trunk or branches so that the underlying wood was left exposed, "pecking", i.e. pecking small holes into the bark or in the wood, "probing", i.e. peering and poking for arthropods in narrow crevices and on the surface, "gleaning", i.e. picking prey off the surface of trunk or branches or "flycatching", i.e. the chasing of flying insects in the air).

Except for six years in the 1970s and 1980s when no Lesser Spotted Woodpeckers were observed in the study area, I collected foraging records for 1-4 birds each year. Between 1 and 9 records were made of each bird. Data from different years were pooled and analysed on a seasonal basis, defining the period November-February as winter, March-April as prebreeding period, May-June as breeding period, and September-October as autumn. In total 460 foraging records were made; winter: males 162 , females 115 ; prebreeding period: males 51 , females 39 ; breeding period: males 43 , females 27 ; autumn: males 15 , females 8 . The tabulated foraging niches for the two sexes are based on the pooled data. The breadth $(B)$ of each of the niche dimensions tree species, substrate condition, tree height choice, foraging height, tree trunk diameter where foraging and the foraging technique used, is expressed using Simpson's index: 


$$
B=\frac{1}{\sum_{\substack{i=1 \\ i=1}}^{n} p_{i}^{2}}
$$

where $p_{i}$ is the proportion of the observations falling in the $i$ th of $n$ categories. $B$ can vary from 1 to $n$ (see Cody 1974). Total niche size is calculated by adding the separate dimension measurements. The degree of intersexual overlap in niche use has been quantitatively determined using Schoener's (1968) overlap index (OI):

$$
O I=\quad 1-1 / 2 \quad \sum_{i=1}^{n}\left|p_{x, i}-p_{y, i}\right|
$$

where $p_{x, i}$ and $p_{y, i}$ are the frequencies for sexes $x$ and $y$, respectively, for the $i$ th category. $O I$ varies from 0 , with no overlap, to 1 for complete overlap. The overlap is considered to be significant when the index value exceeds 0.6 (Wallace 1981).

All tests are two-tailed, and were performed using SPSS 15. Data were analysed using nonparametric tests. Means are presented $\pm 1 \mathrm{SD}$.

\section{RESULTS}

\section{Social behaviour and territory use}

Except for the prebreeding and breeding periods, when male and female Lesser Spotted Woodpeckers appeared together near their nesting tree, I never observed two birds simultaneously. When the parents arrived at the nest tree with food to feed their nestlings, the male and the female came from different directions, each bird from the same part of the forest on the different nestling feeding occasions. After they had fed their nestlings, they left the nest area in the direction they entered. The two ringed males were recorded close to their nesting tree, areas of 300-400 m x $600 \mathrm{~m}$, during the time they had young in their nest. No females were observed in these areas. At the same time, each of the ringed males was seen only once out of 12 and 8 times, respectively, within the areas where the females were foraging. Thus, it seems as if the parents found nestling food in different parts of the territory. I never observed males chasing females; however, when both sexes arrived simultaneously at the breeding tree to feed their nestlings, the female let the male feed the nestlings first.

\section{Foraging behaviour}

\section{Tree species}

With the total observations pooled across years $(n=460)$, most were in grey alder $(44.3 \%)$ and birch $(42.2 \%)$ with rarer occurrences in sallow $(7 \%)$, aspen $(3 \%)$, spruce $(3 \%)$ and rowan $(<1 \%)$. The birds preferred grey alder, aspen and sallow in relation to the abundance of those tree species on the landscape and completely avoided Scots pine which made up about half of the mixed forest. Males did not differ in choice of tree species among the four periods (One-way ANOVA, $\mathrm{F}_{3,270}=0.07, \mathrm{p}=0.976$ ), whereas females differed significantly $\left(\mathrm{F}_{3,187}=10.24, \mathrm{p}<0.001\right)$, with more use of spruce, aspen and rowan during the prebreeding and breeding periods (Table 1). The recorded percentages of the birds' foraging in autumn are uncertain because of a small sample size.

\section{The use of snags, broken trees and live trees}

The birds were observed foraging in snags, which were on average $2.8 \pm 0.8 \mathrm{~m}$ tall $(\mathrm{n}=178)$, in dying broken trees $2.8 \pm 0.8 \mathrm{~m}$ tall $(\mathrm{n}=65)$, and in live trees ranging from $1.5-6 \mathrm{~m}$ tall $(\mathrm{n}=216)$. Both sexes varied in their use of these foraging sites among the four periods (ANOVA, males: $\mathrm{F}_{3}$, ${ }_{270}=3.94, p=0.009$; females: $F_{3,187}=4.17, p=0.007$ ) with increased use of snags and broken trees in the winter compared to the other periods. No significant sexual difference was found in the birds' use of snag, broken tree or live tree, with all observations combined $\left(\chi^{2}=2.45, \mathrm{df}=2, \mathrm{~ns}\right)$ or within each of the prebreeding, breeding, or winter periods considered separately $\left(\chi^{2}=0.49\right.$, 
Table 1. Percentage and number of foraging occurrences by male $(M)$ and female $(F)$ Lesser Spotted Woodpeckers in the winter period (November-February), the prebreeding period (March-April), the breeding period (May-June) and autumn period (September-October).

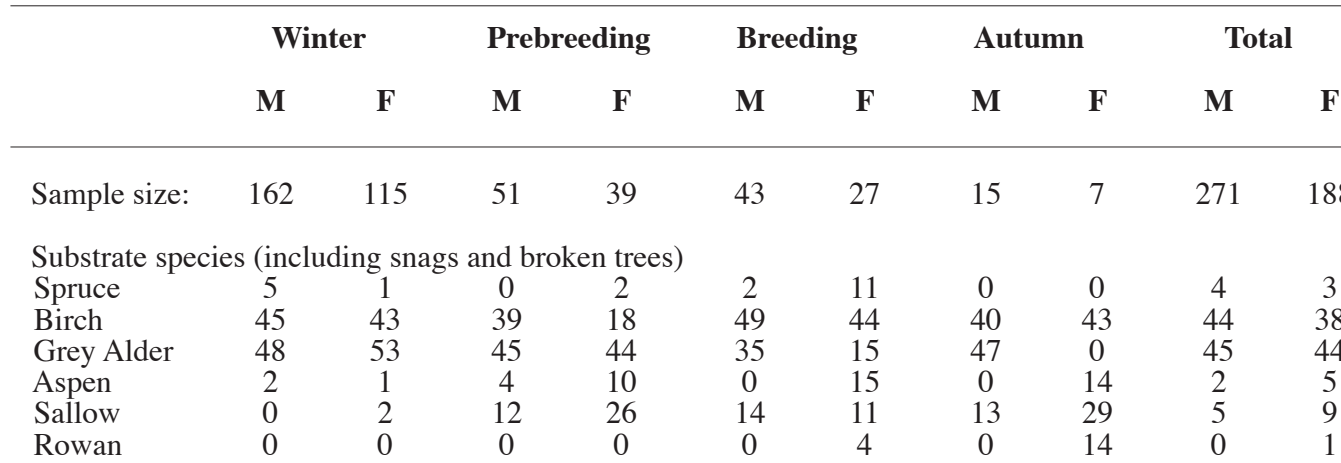

Substrate species (healthy trees only) ${ }^{1)}$

\begin{tabular}{|c|c|c|c|c|c|c|c|c|c|c|}
\hline & 72 & 41 & 22 & 25 & 29 & 20 & 2 & 5 & 125 & 91 \\
\hline Spruce & 0 & 0 & 0 & 4 & 0 & 0 & 0 & 0 & 0 & 1 \\
\hline Birch & 51 & 73 & 32 & 8 & 52 & 55 & 0 & 20 & 47 & 48 \\
\hline Grey alder & 49 & 22 & 36 & 40 & 38 & 15 & 0 & 0 & 43 & 24 \\
\hline Aspen & 0 & 0 & 9 & 12 & 0 & 15 & 0 & 20 & 2 & 8 \\
\hline Sallow & 0 & 5 & 23 & 36 & 10 & 10 & 100 & 40 & 8 & 17 \\
\hline Rowan & 0 & 0 & 0 & 0 & 0 & 5 & 0 & 20 & 0 & 2 \\
\hline \multicolumn{11}{|l|}{ Decay status } \\
\hline Snag & 41 & 40 & 53 & 31 & 26 & 22 & 53 & 29 & 41 & \\
\hline Broken tree & 15 & 24 & 4 & 5 & 7 & 4 & 33 & 0 & 13 & \\
\hline Tree & 44 & 36 & 43 & 64 & 67 & 74 & 13 & 71 & 46 & \\
\hline
\end{tabular}

Condition of substrate

$\begin{array}{lcccccccccc}\text { Dead } & 100 & 100 & 84 & 69 & 49 & 52 & 100 & 71 & 89 & 86 \\ \text { Alive } & 0 & 0 & 16 & 31 & 51 & 48 & 0 & 29 & 11 & 14 \\ & & & & & & & & & & \\ \text { Tree height }(\mathrm{m})^{1)} & 72 & 41 & 22 & 25 & 29 & 20 & 2 & 5 & 125 & 91 \\ <2 & 3 & 0 & 0 & 0 & 0 & 0 & 0 & 0 & 2 & 0 \\ 2-5 & 93 & 98 & 100 & 88 & 100 & 85 & 100 & 100 & 96 & 92 \\ 5.1-10 & 2 & 1 & 0 & 8 & 0 & 7 & 1 & 2 & 0 & 3 \\ & & & & & & & & & & \\ \text { Foraging height }(\mathrm{m})^{1)} & & 19 & 18 & 0 & 3 & 10 & 0 & 0 & 15 & 9 \\ <2 & 81 & 85 & 82 & 100 & 97 & 85 & 100 & 100 & 85 & 90 \\ 2-5 & 0 & 0 & 0 & 0 & 0 & 5 & 0 & 0 & 0 & 1 \\ 5.1-10 & & & & & & & & & \end{array}$

Diameter of foraging site $(\mathrm{cm})$

$\begin{array}{lcccccccccc}<5 & 38 & 44 & 41 & 69 & 88 & 93 & 6 & 71 & 45 & 57 \\ 5-10 & 50 & 51 & 51 & 31 & 12 & 7 & 67 & 29 & 45 & 40 \\ 11-15 & 12 & 5 & 6 & 0 & 0 & 0 & 27 & 0 & 10 & 3 \\ >15 & 0 & 0 & 2 & 0 & 0 & 0 & 0 & 0 & 0 & 0\end{array}$

Foraging technique

$\begin{array}{lcccccccccc}\text { Scaling } & 13 & 2 & 12 & 2 & 0 & 0 & 13 & 0 & 11 & 2 \\ \text { Pecking } & 79 & 63 & 68 & 46 & 53 & 18 & 67 & 0 & 72 & 51 \\ \text { Probing } & 8 & 35 & 16 & 26 & 28 & 21 & 20 & 57 & 13 & 32 \\ \text { Gleaning } & 0 & 0 & 4 & 26 & 19 & 57 & 0 & 43 & 4 & 15 \\ \text { Flycatching } & 0 & 0 & 0 & 0 & 0 & 4 & 0 & 0 & 0 & 0\end{array}$

Notes: ${ }^{1)}$ Sample size in tree species, tree height and foraging height; snags and broken trees not included. 
4.54 and 8.04, respectively, ns). The sexes differed in use of these foraging sites during the autumn $\left(\chi^{2}=8.04, \mathrm{p}=0.018\right)$, but due to a small sample size, the result is uncertain. However, because winter is the season when surface and foliage-dwelling arthropods are expected to be rarest, whereas that food source is expected to be more abundant in the other seasons (which can leave more room for behavioural differences between sexes), it seems reasonable to isolate the winter data and compare it to the three other periods combined ("summer"). Then it was found that the use of the three substrate types by males did not differ seasonally $\left(\chi^{2}=1.93, \mathrm{df}=2\right.$, ns) whereas in winter, females foraged more in snags (40\% vs. 27\%) and broken trees (24\% vs. $4 \%$ ) and less in healthy trees (36\% vs. $69 \%$ ) than during summer $\left(\chi^{2}=23.06, \mathrm{df}=3, \mathrm{p}<0.001\right)$. Furthermore, there was a sexual difference in summer $\left(\chi^{2}=7.26, p=0.026\right)$ with females foraging more in live trees and less in snags and broken trees than males (Fig. 1)

\section{Use of live trees (excluding snags and broken trees)}

When analysing the birds' foraging behaviour in live trees, both sexes differed in the frequency with which they used various tree species during the four periods (ANOVA, males: $\mathrm{F}_{3,124}=7.90$, $\mathrm{p}<0.001$; females: $\left.\mathrm{F}_{3,90}=11.84, \mathrm{p}<0.001\right)$. In

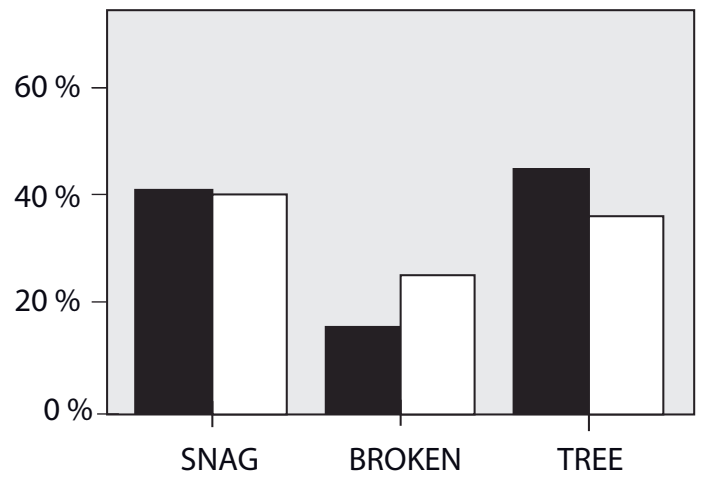

winter males (100\%) and females (95\%) foraged nearly entirely in birch and grey alder, whereas aspen and sallow were frequently used in the other three periods (Table 1). The sexes did not differ in use of tree species, except during the winter $\left(\chi^{2}=6.89, \mathrm{df}=1, \mathrm{p}=0.009\right)$ when females foraged more in birch $(73 \%)$ and less in grey alder $(22 \%)$ than males $(51 \%$ and $49 \%$, respectively).

\section{Tree height and foraging height}

With all observations in healthy trees combined, females used taller trees (average height $3.8 \mathrm{~m}$ ) than males $(3.4 \mathrm{~m})$ in birch (Mann-Whitney, $\mathrm{z}=-2.70, \mathrm{p}=0.007$ ) and grey alder (female: $4.3 \mathrm{~m}$; male: $3.7 \mathrm{~m}$; $\mathrm{z}=-2.50, \mathrm{p}=0.01$ ) but not for aspen (male: $5.0 \mathrm{~m}$, female: $5.0 \mathrm{~m}$ ) or sallow (male: 3.5 $\mathrm{m}$, female: $3.7 \mathrm{~m}$; Table 2). The height of birch trees used for foraging did not vary seasonally for either sex (ANOVA, males: $\mathrm{F}_{2.58}=1.33$, ns; female $\mathrm{F}_{3,43}=1.99$, ns), and females also used similar heights of grey alder throughout the year $\left(\mathrm{F}_{2,21}=1.44, \mathrm{~ns}\right)$. Males, however, used taller grey alder in winter $(3.9 \mathrm{~m})$ than in the prebreeding period (3.2 m; Mann-Whitney, $\mathrm{z}=-1.97, \mathrm{p}=0.049$ ).

I analyzed both the absolute height and the relative height in a tree at which the sexes foraged. With pooled observations, most foraging occurred in the upper half trees for both males

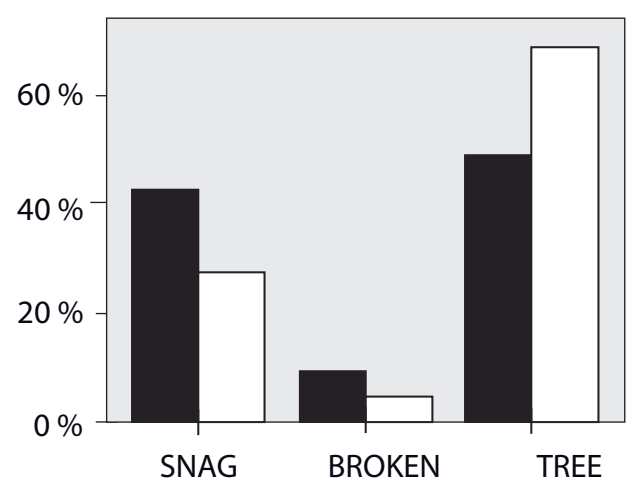

Figure 1. The Lesser Spotted Woodpecker males (black) and females percentage use of dead snags, dying broken trees and live trees for foraging in winter (left) and summer (prebreeding, breeding and autumn periods combined). 
Table 2. The mean tree height $(m)$ (excluding snags and broken trees), foraging height $(m)$, relative foraging height (foraging height:tree height) and diameter of foraging site $(\mathrm{cm})$ used by the woodpeckers, totally for the year. Difference between means are denoted by $*$ in a Mann-Whitney Test (two-tailed). $*=p<0.05, * *=p \leq 0.01$.

\begin{tabular}{|c|c|c|c|c|c|c|}
\hline Tree species & Sex & (n) & Tree height & $\begin{array}{c}\text { Foraging } \\
\text { height }\end{array}$ & $\begin{array}{c}\text { Rel. foraging } \\
\text { height }\end{array}$ & Diameter \\
\hline \multirow[t]{2}{*}{ Birch } & male & (59) & $3.4 \pm 0.9 * *$ & $2.5 \pm 0.7$ & $0.7 \pm 0.1$ & $3.7 \pm 1.4$ \\
\hline & female & (44) & $3.8 \pm 0.7$ & $2.6 \pm 0.7$ & $0.7 \pm 0.1$ & $3.8 \pm 2.5$ \\
\hline Grey & male & (54) & $3.7 \pm 0.8 *$ & $2.6 \pm 0.6 *$ & $0.7 \pm 0.1$ & $4.6 \pm 3.1$ \\
\hline alder & female & (22) & $4.3 \pm 1.0$ & $3.0 \pm 0.8$ & $0.7 \pm 0.1$ & $3.4 \pm 1.1$ \\
\hline \multirow[t]{2}{*}{ Aspen } & male & (2) & 5.0 & 3.3 & 0.7 & 6.5 \\
\hline & female & (7) & 5.0 & 3.2 & 0.9 & 2.6 \\
\hline \multirow[t]{2}{*}{ Sallow } & male & (10) & $3.5 \pm 0.5$ & $2.4 \pm 0.5$ & $0.7 \pm 0.1$ & $2.9 \pm 1.1$ \\
\hline & female & (15) & $3.7 \pm 1.0$ & $2.7 \pm 0.8$ & $0.7 \pm 0.1$ & $2.7 \pm 1.0$ \\
\hline
\end{tabular}

(mean relative height $0.72 \pm 0.12, \mathrm{n}=125$ ) and females $(0.70 \pm 0.18, \mathrm{n}=91)$ and the sexes did not differ ( $\mathrm{z}=-1.62, \mathrm{~ns}$; Table 2). Similarly, there was no significant difference between the sexes in the frequency they foraged in the three height categories $\left(<2 \mathrm{~m}, 2-5 \mathrm{~m}\right.$ and $>5 \mathrm{~m} ; \chi^{2}=4.2, \mathrm{df}=3$, $\mathrm{p}=0.122$; Table 1). Because the patterns of relative height with respect to season and tree species were similar to the patterns of absolute height, I only present the results for the latter here. With tree species considered separately, there was still no difference between the sexes for mean foraging height in birch (male: $2.5 \mathrm{~m}$, female: $2.6 \mathrm{~m}$ ), whereas females $(3.0 \mathrm{~m})$ foraged higher than males ( $2.6 \mathrm{~m}$; Mann-Whitney, $\mathrm{z}=-1.96, \mathrm{p}=0.05$ ) in grey alder (Table 2). When analysing season, the foraging height of neither sex varied in grey alder, aspen or willow but both sexes varied in foraging heights in birch (ANOVA, males: $\mathrm{F}_{2.58}=8.12$, $\mathrm{p}=0.001$; females: $\left.\mathrm{F}_{3.43}=3.93, \mathrm{p}=0.015\right)$. In particular, both sexes foraged at lower heights in winter (males mean: $2.2 \pm 0.65$ m; females: 2.4 $\pm 0.60 \mathrm{~m})$ and highest in the prebreeding period (males: $2.8 \pm 0.27 \mathrm{~m} ; \mathrm{z}=-2.43$, $\mathrm{p}=0.015$; females: $3.5 \pm 0.71 \mathrm{~m}, \mathrm{z}=-1.98, \mathrm{p}=0.048$ ).

\section{Diameter of foraging sites}

Overall, males foraged on sites with a greater mean diameter than females (males: $5.9 \pm 3.2 \mathrm{~cm}$, $\mathrm{n}=271$; females: $4.6 \pm 2.6 \mathrm{~cm}, \mathrm{n}=188 ; \mathrm{z}=-4.44$, $\mathrm{p}<0.001$; Table 1 ). There was seasonal variation in the diameter of substrate used by both males (ANOVA, males: $\mathrm{F}_{3,270}=17.09, \mathrm{p}<0.001$ ) and females $\left(\mathrm{F}_{3,187}=13.62, \mathrm{p}<0.001\right)$. Both sexes used the smallest mean diameter in the breeding period (males: $3.3 \pm 1.1 \mathrm{~cm}, \mathrm{n}=43$; females: $2.8 \pm 1.2 \mathrm{~cm}$, $\mathrm{n}=27$ ) and greatest in autumn (males: $8.5 \pm 2.6 \mathrm{~cm}$, $\mathrm{n}=15$ ) or in winter (females: $5.4 \pm 2.8 \mathrm{~cm}, \mathrm{n}=115$ ).

Within substrate types, males foraged on larger diameters than females of snags (males: 7.61 \pm 3.0 $\mathrm{cm}$; females $5.87 \pm 2.4 \mathrm{~cm} ; \mathrm{z}=-3.84, \mathrm{p}<0.001)$, broken trees (males: $7.2 \pm 2.6 \mathrm{~cm}$; females: 5.5 $\pm 2.7 \mathrm{~cm} ; \mathrm{z}=-2.80, \mathrm{p}=0.005)$ and in live trees (males: $4.06 \pm 2.4 \mathrm{~cm}, \mathrm{n}=125$; females: $3.4 \pm 2.0$ $\mathrm{cm}, \mathrm{n}=91 ; \mathrm{z}=-3.092, \mathrm{p}=0.002$ ). No significant between-sex differences was found for foraging site diameters of live birch, grey alder, aspen or sallow (Table 2).

\section{Foraging technique}

Bark-pecking was the main technique used 
across all periods by both sexes except in the breeding period when females used gleaning most (Table 1). The sexes differed in foraging techniques in each of the periods $\left(\chi^{2}=13.2-37.6\right.$, $\mathrm{df}=2-3, \mathrm{p}<0.01)$. The most marked difference is that males used scaling and pecking more and gleaning less than females in the prebreeding and breeding periods.

\section{Foraging niche and intersexual niche overlap}

Males and females showed minor differences in foraging niche dimensions (Table 3 ) and overlapped significantly in all foraging dimensions except foraging technique (Table 4), in which females tended to have larger foraging niche dimensions in the winter and prebreeding periods (Fig. 2). Thus, as suggested, females apparently demonstrated a behavioural plasticity in foraging niche resulting in some broader niche than that of males in the winter and prebreeding periods.

The foraging niche dimensions were smaller in winter for use of live tree species, substrate condition and foraging technique compared to those in the other periods, suggesting a narrower repertoire in foraging behaviour in the winter. Although significantly different only in the breeding period (and autumn, small sample size), the overlap values for the sexes were relatively small for foraging technique in all periods. Thus, the sexes of the nearly monomorphic Lesser Spotted Woodpecker differed in foraging behaviour in the breeding period, mainly because males used pecking more and gleaning less than females.

\section{DISCUSSION}

As the pair-bond of Lesser Spotted Woodpeckers may extend over several years and the birds often stay for life where first settled (Wiktander 1998), it is noteworthy that I never observed two birds together, except in the prebreeding and breeding periods. Even in these periods, the mates usually seemed to stay within different parts of the territory (Hogstad 2009). A probable explanation for an intersexual separation of a territory may be advantages of minimizing search costs per food item. If this is the case for the Lesser Spotted Woodpecker, an adoption of mutually exclusive territories during the winter may be an adaptation for securing food without energy-wasting conflicts over foraging sites in a time when weather is harsh and energy demands are high (e.g. Saari \& Mikusinski 1996, Hogstad \& Stenberg 2005, Steen et al. 2006). A correlation between the breeding density of the Lesser

Table 3. Foraging niche dimensions of male $(M)$ and female $(F)$ Lesser Spotted Woodpecker during the winter, prebreeding and breeding periods, and autumn.

\begin{tabular}{|c|c|c|c|c|c|c|c|c|c|c|}
\hline & \multicolumn{2}{|c|}{ Winter } & \multicolumn{2}{|c|}{ Prebreed. } & \multicolumn{2}{|c|}{ Breeding } & \multicolumn{2}{|c|}{ Autumn } & \multicolumn{2}{|c|}{ Total } \\
\hline & $\mathbf{M}$ & $\mathbf{F}$ & $\mathbf{M}$ & $\mathbf{F}$ & $\mathbf{M}$ & $\mathbf{F}$ & $\mathbf{M}$ & $\mathbf{F}$ & $\mathbf{M}$ & $\mathbf{F}$ \\
\hline Snag, broken tree, tree & 2.60 & 2.88 & 2.14 & 1.97 & 1.92 & 1.67 & 2.46 & 1.70 & 2.52 & 2.62 \\
\hline Tree species ${ }^{1)}$ & 2.00 & 1.71 & 3.41 & 3.21 & 2.35 & 2.78 & 1.00 & 3.57 & 2.45 & 3.09 \\
\hline Substrate condition & 1.00 & 1.00 & 1.37 & 1.75 & 2.00 & 2.00 & 1.00 & 1.70 & 1.00 & 1.24 \\
\hline Tree height ${ }^{1)}$ & 1.15 & 1.04 & 1.00 & 1.27 & 1.00 & 1.34 & 1.00 & 1.00 & 1.08 & 1.17 \\
\hline Foraging height ${ }^{1)}$ & 1.44 & 1.34 & 1.42 & 1.00 & 1.06 & 1.36 & 1.00 & 1.00 & 1.38 & 1.22 \\
\hline Diam. foraging site & 2.45 & 2.19 & 2.31 & 1.75 & 1.27 & 1.24 & 1.90 & 1.70 & 2.41 & 2.06 \\
\hline Foraging technique & 1.54 & 1.92 & 1.98 & 2.88 & 2.53 & 2.48 & 1.98 & 1.96 & 8.43 & 9.56 \\
\hline
\end{tabular}

Notes: 1) Sample sizes in tree species, tree height and foraging height do not include dead snags or dying broken trees. 
Table 4. Intersexual overlap (OI) for male and female Lesser Spotted Woodpecker (Schoener's index; see Methods). OI varies from 0 , with no overlap, to 1 for complete overlap. The overlap is considered to be significant when the index value exceeds 0.6.

\begin{tabular}{lccccc}
\hline & Winter & Prebreeding & Breeding & Autumn & Total \\
\hline $\begin{array}{l}\text { Snags, broken } \\
\text { trees, trees }\end{array}$ & 0.91 & 0.78 & 0.93 & 0.94 & 0.94 \\
Tree species ${ }^{1)}$ & 0.63 & 0.76 & 0.77 & $\mathbf{0 . 3 9}$ & 0.80 \\
Condition substrate & 1.00 & 0.85 & 0.99 & 0.71 & 0.97 \\
Tree height ${ }^{1)}$ & 0.97 & 0.92 & 0.84 & 0.98 & 0.97 \\
Foraging height ${ }^{1)}$ & 0.99 & 0.93 & 0.87 & 0.99 & 1.00 \\
Diam. foraging site & 0.99 & 0.72 & 0.99 & 0.89 & 0.88 \\
Foraging technique & 0.73 & 0.63 & $\mathbf{0 . 5 8}$ & $\mathbf{0 . 2 0}$ & 0.70 \\
\hline
\end{tabular}

Notes: 1) Sample sizes in tree species, tree height and foraging height do not include dead snags or dying broken trees.

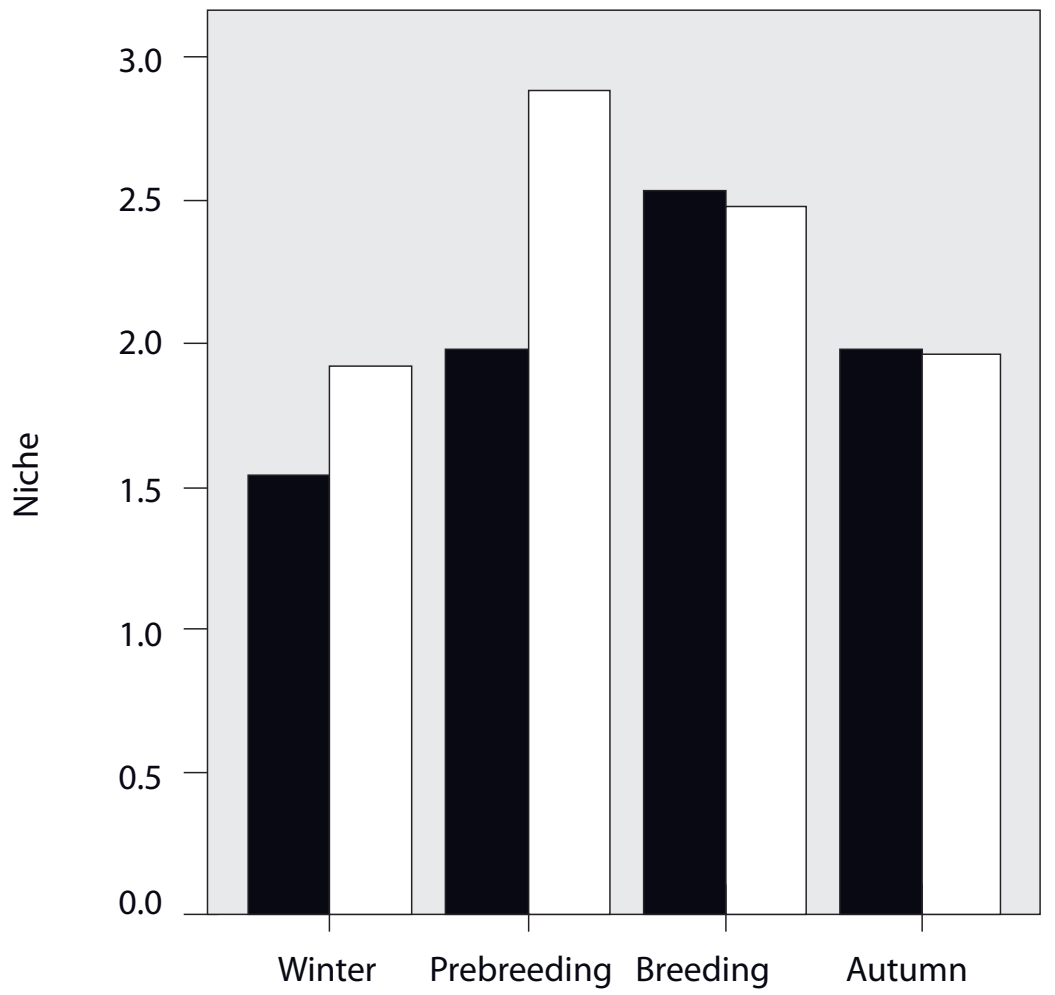

Figure 2. Niche breadth dimensions of foraging techniques used by male (black) and female Lesser Spotted Woodpeckers in four periods of the year. Based on Table 3. 
Spotted Woodpecker and mean temperatures in January and February was explained by energetic problems faced by the species in severe winters (Saari \& Mikusinski 1996).

In the nestling period, the occurrence of living insects surely gives a richer food supply than in the winter. However, in south Sweden, Wiktander et al. (2001) found that the nesting success was positively associated with the ambient temperature during incubation and brooding, suggesting that energy supply in the breeding period may also be limited. If so, the unpredictable and variable weather in the Budal subalpine woodland area, where the ambient temperature in winter frequently is below $-20^{\circ} \mathrm{C}$ and the temperature in June often is below zero (see Hogstad 2009) probably means that foraging is difficult for the woodpeckers year-round. Seeking for food in separate parts of the territory could therefore reduce difficulties for the mates in finding sufficient food for themselves and their offspring. A corresponding low spatial overlap in the breeding season has been found for the nearly monomorphic Middle Spotted Woodpecker Dendrocopos medius (Pettersson 1984, Pasinelli et al. 2001).

Reducing spatial overlap may be one way the sexes reduce competition for food but I also observed that males and females differed in foraging behaviour and technique. The slightly divergent foraging niches, especially outside the winter period, seem to be based primarily on foraging site selection and techniques. In particular, males used scaling and pecking more than females, which on the other hand used probing and gleaning more than males. A male's bill is barely larger than a female's so it is difficult to say whether males are more efficient at foraging in cracks and crevices on rougher bark surfaces. In addition, it is difficult to see how the females' greater propensity to glean prey from sites of smaller diameters, and to forage higher and use more live trees outside winter can be related directly to the small degree of bill size dimorphism.
Sexual differences in foraging behaviour among woodpeckers are often accompanied by sexual size dimorphism, e.g. bill size, tail- and tarsuslengths (Kilham 1965, Hogstad 1976, 1978, Aulén \& Lundberg 1991) and have been associated with the spacing system of a species (Aulén \& Lundberg 1991, Stenberg \& Hogstad 2004). Thus, foraging differences between the sexes should be strongest when males and females inhabit a common territory and less marked when territories are spatially divided. Accordingly, foraging techniques were more divergent between male and female Lesser Spotted Woodpeckers in the pre-breeding and breeding periods when the mates foraged in the vicinity of their nesting tree.

If the sexual foraging differences found for the Lesser Spotted Woodpecker are not related to bill size dimorphism, spatial partitioning of the habitat may be caused by social dominance where the larger and dominant male displaces the female, forcing her to forage in the less optimal parts of the habitat as in some other woodpeckers (Peters \& Grubb 1983, Hogstad 1991, Matthysen et al. 1991, Osiejuk 1994, Pasinelli 2000). Male Lesser Spotted Woodpeckers are not much larger than females and I never observed agonistic behaviours between pairs in this study; however, when both sexes arrived at the nest tree simultaneously, the female waited to enter the nest hole until the male had fed the nestlings and left the tree. Furthermore, in a spruce-dominated mixed forest in south Norway I earlier observed that a male chased a female in winter so males may be socially dominant (Hogstad 1978).

Social dominance plays a major role in determining niche breadth and degree of niche overlap, both between different species (e.g. Morse 1974) and between the sexes (e.g. Peters \& Grubb 1983, Hogstad 1991, Hogstad \& Stenberg 2004). If Lesser Spotted Woodpecker males are socially dominant to females, they may specialize on the preferred parts of the habitat and so the fundamental niche breadth of males should be narrower than that of females. In the present study, the niche breadth of the foraging technique of males 
tended to be narrower than that of females in the winter and prebreeding periods. In the breeding period, however, the niche breadth of males was slightly wider than that of females. This may possibly be connected to the males' significantly greater contribution to nestling feeding than that of females (Hogstad 2009), especially during the last ten days of the nestling period. Probably the male increased his feeding rate by using a wider range of foraging techniques and also changed his foraging sites during this phase of the breeding season. However, whether he used more profitable foraging sites than females is unknown.

\section{ACKNOWLEDGEMENTS}

I am grateful to Karen Wiebe for providing valuable comments on an earlier draft and for improving the English.

\section{SAMMENDRAG}

\section{Kjønnsforskjell i næringssøket hos dvergspett}

Næringssøket hos dvergspett ble undersøkt i en subalpin skog (550-650 moh) i Budal, $90 \mathrm{~km}$ sør for Trondheim. Skogen består stort sett av furu og bjørk, med spredte innslag av gran, osp, rogn, gråor og selje, de to siste treslagene vokser relativt vanlig langs bekker og elver.

Totalt 460 observasjoner ble foretatt i årene 1972-2007. Data fra de forskjellige årene ble slått sammen og analysert i periodene: vinter (november - februar), tiden før hekking (mars - april), hekketid (mai - juni) og høst (september - oktober).

Fuglene søkte etter føde i størst grad i bjørk (43 $\%)$ og gråor (44 \%). Det ble ikke registret noen kjønnsforskjell i bruk av døde stubber, døende eller levende trær, og begge kjønn søkte etter føde utelukkende i dødt trevirke vinters tid. Det var heller ingen kjønnsforskjell i bruk av forskjellige treslag bortsett fra om vinteren; da ble hunnene sett oftere i bjørk (73 \%) og mindre i gråor (22 $\%$ ) enn hannene (henholdsvis $51 \%$ og $49 \%$ ).
Hunnene søkte etter føde i større bjørker (gj. sn. høyde $3.8 \mathrm{~m})$ og gråor $(4.3 \mathrm{~m})$ enn hannene (henholdsvis $3.4 \mathrm{~m}$ og $3.7 \mathrm{~m}$ høye), men benyttet substrat med mindre diameter (hunner gj.sn. 4.6 $\mathrm{cm}$, hanner $5.9 \mathrm{~cm})$. Det var en markert kjønnsforskjell i måten å søke etter føde på: hannene benyttet barkskalling (systematisk fjerning av barken på stamme eller greiner slik at veden syntes) og hullhakking (hakket små hull i barken eller veden) mer enn hunnene i alle periodene, mens hunnene s $\varnothing$ kte oftere etter føde i barksprekker og på overflaten av barken enn hannene om vinteren og i tiden før hekking. Hunnene syntes å ha en videre næringss $\varnothing \mathrm{ks}-n i s j e ~ e n n$ hannene vinters tid og i tiden før hekking.

Siden en hann og en hunn aldri ble observert sammen (unntatt like før og under hekking), kan det synes som om paret søker etter føde i forskjellige deler av territoriet. Kjønnenes deling av ressursene ved næringss $\varnothing \mathrm{k}$ i ulike deler av territoriet samt forskjell i måten å søke etter føde på, indikerer at dvergspetten trolig reduserer konkurransen om føden mellom kjønnene i subalpine områder hvor vintertemperaturen ofte er nede $\mathrm{i}$ 20-30 kuldegrader.

\section{REFERENCES}

Alatalo, R. 1978. Resource partitioning in Finnish woodpeckers. - Ornis Fennica 55: 49-59.

Andersson, M. 1994. Sexual selection. Princeton University Press, New Jersey.

Aulén, G. 1988. Ecology and distribution history of the White-backed Woodpecker Dendrocopos leucotos in Sweden. $\mathrm{PhD}$ thesis, Uppsala, Sweden.

Aulén, G. \& Lundberg, A. 1991. Sexual dimorphism and patterns of territory use by the White-backed Woodpecker Dendrocopos leucotos. - Ornis Scandinavica 22: 60-64.

Cody, M.L. 1974. Competition and the Structure of Bird Communities. Monographs in Population Biology, Vol. 7. Princeton University Press, New Jersey.

Cramp, S. (ed.) 1985. The Birds of the Western Palearctic, Vol.IV. Oxford University Press, Oxford.

del Hoyo, J., Elliot, A. \& Sargatal, J. (eds.) 2002. Handbook of the Birds of the World, Vol 7. Lynx Edicions, Barcelona.

Glutz von Blotzheim, U.N. \& Bauer, K.M. 1980. Hand- 
buch der Vögel Mitteleuropas. Vol. 9. AULA Verlag, Wiesbaden. (In German)

Hogstad, O. 1976. Sexual dimorphism and divergence in winter foraging behaviour of Three-toed Woodpeckers Picoides tridactylus. - Ibis 118: 41-50.

Hogstad, O. 1978. Sexual dimorphism in relation to winter foraging and territorial behaviour of the Three-toed Woodpecker Picoides tridactylus and three Dendrocopos species. - Ibis 120: 198-203.

Hogstad, O. 1991. The effect of social dominance on foraging by the Three-toed Woodpecker Picoides tridactylus. - Ibis 133: 271-176.

Hogstad, O. 2009. Sexual differences of labour during breeding activities and territory use in the Lesser Spotted Woodpecker Dendrocopos minor. - Ornis Norvegica 32: 42-48.

Hogstad, O. \& Stenberg, I. 2004. Sexual dimorphism in relation to winter foraging in the White-backed Woodpecker (Dendrocopos leucotos). - Journal of Ornithology 145: 321-326.

Hogstad, O. \& Stenberg, I. 2005. Sexual differences in physical condition in the White-backed Woodpecker Dendrocopos leucotos in relation to habitat type and across seasons. - Ornis Fennica 82: 26-31.

Kilham,L. 1965. Differences in feeding behavior of male and female Hairy Woodpeckers. - Wilson Bulletin 77: 134-145.

Kålås, J.A., Viken, A. \& Bakken, T. (red. ) 2006. Norsk Rødliste 2006 - 2006 Norwegian Red List. Artsdatabanken, Norway.

Matthysen, E., Grubb, T.C. Jr. \& Cimprich, D. 1991. Social control of sex-specific foraging behaviour in Downy Woodpeckers, Picoides pubescens. - Animal Behavior 42: 515-517.

Mikusinski, G. 1997. Woodpeckers in Time and Space. $\mathrm{PhD}$ thesis Swedish University of Agricultural Sciences, Uppsala, Sweden.

Morse, D.H. 1974. Niche breadth as a function of social dominance. - American Naturalist 108: 818830.

Møller, A.P. 1994. Sexual Selection and the Barn Swallow. Oxford University Press, Oxford.

Nilsson, S.G., Olsson, O., Svensson, S. \& Wiktander, U. 1992. Population trends and fluctuations in Swedish woodpeckers. - Ornis Svecica 2: 13-21.

Olsson, O. 1998. Through the eyes of a woodpecker: understanding habitat selection, territory quality and reproductive decisions from individual behaviour. $\mathrm{PhD}$ thesis, Lund, Sweden.

Osiejuk, T.S. 1994. Sexual dimorphism in foraging behaviour of the Great Spotted Woodpecker Dendrocopos major during winters with rich crops of scots pine cones. - Ornis Fennica 71: 144-150.

Pasinelli, G. 2000. Sexual dimorphism and foraging niche partitioning in the Middle Spotted Woodpecker Dendrocopos medius. - Ibis 142: 635-644.

Pasinelli, G.,Hegelbach, J. \& Reyer, H.U. 2001. Spacing behavior of the Middle Spotted Woodpecker in central Europe. - Journal of Wildlife Management 65: 432-441.

Peters, W.D. \& Grubb, T.C. Jr. 1983. An experimental analysis of sex-specific foraging in the Downy Woodpecker, Picoides pubescens. - Ecology 64: 1437-1443.

Pettersson, B. 1984. Ecology of an isolated population of the middle spotted woodpecker, Dendrocopos medius (L.), in the extinction phase. - Swedish University of Agricultural Sciences, Department of Wildlife Ecology, Report No. 11, Uppsala.

Pynnönen, A. 1939. Beiträge zur Kenntnis der Biologie finnischer Spechte. I. - Ann. Zool. Soc. Zool.Bot. Fenn. Vanamo 7: 1-166.

Rossmanith, E., Höntsch, K., Blaum, N. \& Jeltsch, F. 2007. Reproductive success and nestling diet in the Lesser Spotted Woodpecker (Dendrocopos minor): the early bird gets the caterpillar. Journal of Ornithology 148: 323-332.

Saari, L. \& Mikusinski, G. 1996. Population fluctuations of woodpecker species on the Baltic island of Aasla, SW Finland. - Ornis Fennica 73: 168-178.

Schoener, T. 1968. The Anolis lizards of Bimini: Resource partitioning in a complex fauna. - Ecology 49: 704-726.

Selander, R.K. 1966. Sexual dimorphism and differential niche utilization in birds. - Condor 68: 113-151.

Slatkin, M. 1984. Ecological causes of sexual dimorphism. - Evolution 38: 622-630.

Steen, R., Selås, V. \& Stenberg, I. 2006. Impact of weather on annual fluctuations in breeding numbers of Lesser Spotted Woodpecker Dendrocopos minor in Norway. - Ardea 94: 225-231.

Stenberg, I. \& Hogstad, O. 2004. Sexual dimorphism in relation to winter foraging in the white-backed woodpecker (Dendrocopos leucotos). - Journal of Ornithology 145: 321-326.

Tiainen, J. 1985. Monitoring bird populations in Finland. - Ornis Fennica 62: 80-89.

Török, J. 1990. Resource partitioning among three woodpecker species Dendrocopos spp during the breeding season. - Holarctic Ecology 13: 257-264.

Wallace, R.K. Jr. 1981. An assessment of diet-overlap indexes. - Trans. Am. Fish. Soc. 110: 72-76.

Wiens, J.A., Martin, S.C., Holthaus, W. \& Iwen, F.A. 1970. Metronome timing in behavioural ecology studies. - Ecology 51: 350-352.

Wiktander, U. 1998. Reproduction and survival in the Lesser Spotted Woodpecker. Effects of life history, mating system and age. $\mathrm{PhD}$ thesis, Lund, Sweden.

Wiktander, U., Nilsson, S.G., Olsson, O. \& Stagen, A. 1994. Breeding success of a Lesser Spotted Woodpecker Dendrocopos minor. - Ibis 136: 318-322.

Wiktander, U., Olsson, O. \& Nilsson, S.G. 2001. Annual and seasonal reproductive trends in the Lesser Spotted Woodpecker Dendrocopos minor. Ibis 143: 72-82. 